\title{
Isolation and characterization of a 29-kDa glycoprotein with antifungal activity from bulbs of Urginea indica
}

\author{
A.V. Deepak, ${ }^{a}$ G. Thippeswamy, ${ }^{a}$ M.N. Shivakameshwari, ${ }^{b}$ and Bharathi P. Salimath ${ }^{\mathrm{a}, *}$ \\ a Department of Applied Botany and Biotechnology, University of Mysore, Manasagangotri, Mysore 570 006, Karnataka, India \\ ${ }^{\mathrm{b}}$ Department of Studies in Botany, Bangalore University, Bangalore, India
}

Received 30 September 2003

\begin{abstract}
In this study an antifungal protein from Urginea indica bulbs was purified to homogeneity by acid precipitation, Diol 300 Gelfiltration, and $\mathrm{C}_{18}$ reverse phase HPLC. Its molecular mass was estimated to be $29 \mathrm{kDa}$ and periodic acid-Schiff (PAS) staining showed that identified antifungal molecule is a glycoprotein. The neutralization of antifungal activity after periodate oxidation of $29 \mathrm{kDa}$ glycoprotein suggests that the glycan part of the molecule appears to be involved in antifungal activity. N-terminal amino acid sequence of the purified protein was determined as SQLKAXIXDF. This sequence had no sequence similarity with any antifungal proteins. A polyclonal antiserum was raised against purified protein and used in immunolocalization analysis. Results suggest that it is localized to the cell wall of the bulb. Antifungal tests have demonstrated that $U$. indica protein exerts a fungistatic effect. It completely inhibits the germination of spores and hyphal growth of Fusarium oxysporum.
\end{abstract}

(c) 2003 Elsevier Inc. All rights reserved.

Keywords: Urginea indica; Cell wall; Antifungal glycoprotein; Fusarium oxysporum

The antifungal proteins from plants could either be pathogen-induced proteins or constitutively expressed proteins. Low-molecular mass inhibitory compounds such as phenols, melanins, tannins or phytoalexins along with the pathogen-related proteins inhibit the growth of pathogens [1,2]. Pathogen-related proteins (PR) are divided into five classes [3]. PR protein classes 2 and 3 contain $\beta-1,3$-glucanases and chitinases, respectively, which can hydrolyze fungal cell wall and exhibit strong antifungal activities in vitro [4-7]. Class $1 \mathrm{PR}$ proteins contain related proteins found in a wide variety of plants with molecular masses of approximately $15 \mathrm{kDa}$ that are induced on infection by tobacco mosaic virus. Class 4 PR proteins include acidic proteins with molecular masses of $13-14.5 \mathrm{kDa}$ that have sequence similarity with wound-induced proteins of potato. The mechanism of action of PR protein classes 1 and 4 remains unknown. Class 5 PR proteins include a number of proteins called thaumatin-like

\footnotetext{
${ }^{*}$ Corresponding author. Fax: +91-821-241-1467.

E-mail address: salimath2000@yahoo.com (B.P. Salimath).
}

proteins [8-10]. Several constitutively expressed antifungal proteins include cysteine-rich small proteins [11,12], thionins [13], ribosome inactivating proteins [14], lipid-transfer proteins [15,16], chitin binding proteins $[17,18]$, and proteinase inhibitors. These proteins can inhibit a wide variety of phytopathogenic fungi, but display different potencies according to the target microorganism.

Several studies suggest that antimicrobial peptides may have direct antimicrobial activity in vivo, especially the enhanced resistance to microbial pathogens conferred to transgenic plants over expressing thionins $[19,20]$, defensin [12], or LTP [21]. Their constitutive expression and external localization in some plant cells has been described [22]. The antimicrobial peptides contribute to the innate immunity, which refers to the first line defense, limiting infection in the early hours of microbial attack. The concept of innate immunity in plants is becoming relevant after the reappearance of the subject as a central defense mechanism in mammals and insects [23]. In fact unlike phytoalexins, which can have adverse effects in plants, antifungal proteins do not seem 
to be phytotoxic and attain high level in seeds, tubers, etc. where they are believed to play a role as protectants.

Urginea is one of the extremely interesting polytypic genera with about 100 species and is represented in India by nine species [24,25]. Urginea indica is also called as Indian squill. Squill bulb has long been used as a source of medicinal product with pharmaceutical and biocidal applications. Bufadienolides of the squill are glycosides used as cardio-tonic agents. The toxicity of the squill bulb is attributed to its scilliroside content [26,27]. During the course of screening plants for novel antifungal activity, we found that a high molecular weight fraction of an extract from bulbs of $U$. indica exhibited potent and broad-spectrum antifungal activity against many agronomically important pathogenic fungi.

We describe in this report the isolation and characterization of a $29 \mathrm{kDa}$ antifungal protein from bulbs of $U$. indica. Periodic acid-Schiff staining showed that it is a glycoprotein. N-terminal sequence analysis of the $29 \mathrm{kDa}$ protein revealed that it does not share any sequence homology with the known antifungal proteins. We have raised neutralizing antibodies against the purified antifungal glycoprotein. The glycoprotein exhibited potent antifungal activity towards commonly encountered agronomically harmful fungi Fusarium oxysporum. In bulb sections of $U$. indica the protein was predominately localized in the epidermal cell layers.

\section{Materials and methods}

The bulbs of $U$. indica were collected from various forest areas in Karnataka, India. Shim-pack Diol $300(7.9 \mathrm{~mm} \mathrm{ID} \times 50 \mathrm{~cm})$ gel filtration column and Shim-pack -CLC $\mathrm{C}_{18}$ reverse-phase column $(10 \mu \mathrm{m}$ $0.46 \times 25 \mathrm{~cm}$ ) were purchased from Shimadzu, Kyoto, Japan. Molecular mass standard for SDS-PAGE was from MBI Fermentas. FITC-tagged goat anti-rabbit $\operatorname{IgG}$ was obtained from Genei, Bangalore, India. All plant pathogens, including $F$. oxysporum, Rhizoctonia solani, Alternaria tenuissima, Alternaria alternata, Aspergillus niger, Sclerotium rolfsii, and Colletotrichum dematium were isolated from infected seed samples. All reagents were of the highest grade commercially available.

\section{Purification of antifungal protein}

Bulbs of $U$. indica $(100 \mathrm{~g})$ were homogenized in $200 \mathrm{ml}$ of $25 \mathrm{mM}$ Tris- $\mathrm{HCl}$ buffer, $\mathrm{pH} 6.8$. The extract was centrifuged at $10,000 \mathrm{rpm}$ for 10 min at $4{ }^{\circ} \mathrm{C}$ and supernatant was subjected to acid precipitation, where $\mathrm{pH}$ of the solution was brought down to a $\mathrm{pH} 2.5$ by drop-wise addition of $0.1 \mathrm{~N} \mathrm{HCl}$. The acidified solution was placed at $4{ }^{\circ} \mathrm{C}$ overnight and the precipitate that formed was removed by centrifugation as above. The supernatant obtained was dialyzed extensively against distilled water with a $12 \mathrm{kDa}$ cut-off dialysis membrane. The $\mathrm{pH}$ of the dialysate was restored to $\mathrm{pH} 7$ for neutralization. The dialysate was concentrated using BioTron vacuum freeze-dryer before being used for fractionation on a Sephadex G-100 gel filtration column equilibrated with $25 \mathrm{mM}$ Tris- $\mathrm{HCl}$ buffer, $\mathrm{pH}$ 6.8. Proteins were eluted at a flow rate of $15 \mathrm{ml} / \mathrm{h}$. The elution profile was monitored at $280 \mathrm{~nm}$ using Hitachi U-2000 Spectrophotometer. The antifungal activity was assayed for every third tube before pooling the activity peaks. The pooled active fraction of peak 2 (Fig. 1A) was applied to Shim-pack Diol 300 gel filtration column that had been equilibrated with $25 \mathrm{mM}$ Tris- $\mathrm{HCl}$ buffer,
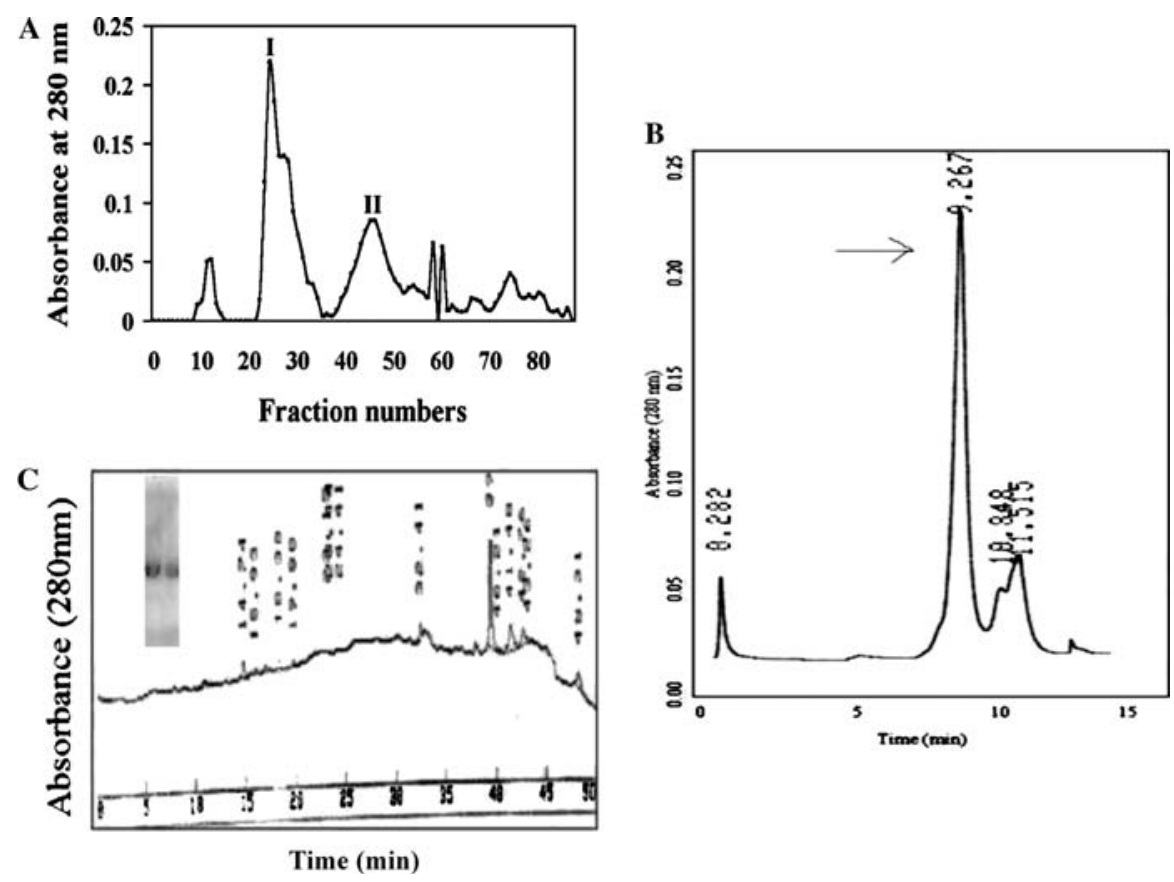

Time (min)

Fig. 1. (A) Purification of antifungal protein from $U$. indica. Dialysed and neutralized acid extract (200 mg) was applied on a Sephadex G100 column $(1 \times 100 \mathrm{~cm})$, Column was eluted at a flow rate of $15 \mathrm{ml} / \mathrm{h}$ with Tris- $\mathrm{HCl}$ buffer, $\mathrm{pH} 6.8$. Every third fraction was assayed for antifungal activity. (B) Fractionation of active fraction from the Sephadex G-100 by Diol-300 HPLC gel filtration column. The arrow indicates the major peak with antifungal activity. (C) The peak marked in (B) was further purified by chromatography with gradient on $\mathrm{C}_{18} \mathrm{RP}$-HPLC. About 30 mg of protein was applied to a Shim pack CLC-C $\mathrm{C}_{18}(25 \mathrm{~cm})$ column equilibrated with $0.1 \% \mathrm{TFA}$ in water. Column was eluted at a flow rate of $1 \mathrm{ml} / \mathrm{min}$ and elution profile was monitored at $280 \mathrm{~nm}$. Inset: Periodic acid-Schiff staining of purified antifungal glycoprotein. 
$\mathrm{pH}$ 6.8. Proteins were eluted from the column at a flow rate of $1 \mathrm{ml} / \mathrm{min}$ with Shimadzu HPLC system model LC 10AS. Major peak containing antifungal activity was concentrated and purified further on HPLC Shim pack $\mathrm{C}_{18}$ reverse phase column equilibrated with $0.1 \%$ trifluoroacetic acid (TFA) in water. After a 10 min washing phase, proteins were eluted by a linear gradient of acetonitrile $0-80 \%$ in $0.1 \%$ TFA at a flow rate of $1 \mathrm{ml} / \mathrm{min}$ for $60 \mathrm{~min}$. Fractions were collected and concentrated to dryness using a vacuum concentrator. Protein concentration was determined by Lowry's method and assayed for antifungal activity. A major peak that eluted at 50\% acetonitrile showed strong antifungal activity. SDS-PAGE showed that this fraction contained a homogeneous protein with a molecular mass of approximately $29 \mathrm{kDa}$.

\section{Characterization of antifungal protein}

Protein analysis. Protein concentration was determined by Lowry's method, using bovine serum albumin (BSA) as reference standard. Electrophoretic separation was performed following the method of Laemmli [28], using $12 \%$ polyacrylamide gel with a $5 \%$ polyacrylamide stacking gel. Electrophoresis was done at $100 \mathrm{~V}$. The resulting gel was stained with silver reagents. The molecular weight of the protein was determined by comparison of its electrophoretic mobility with those of the molecular weight marker proteins.

Analysis of carbohydrate content by total sugar estimation. The presence of sugars bound to the protein was determined by phenol sulfuric acid method of Dubois et al. [29]. Glucose $(0-25 \mu \mathrm{g})$ was used as reference standard.

Periodic acid-Schiff (PAS) staining for glycoprotein. SDS-PAGE was carried out in slab gels according to the method described in electrophoresis. After electrophoresis the gel was placed in fixative ( $7.5 \%$ acetic acid), rocked gently for $60 \mathrm{~min}$. To oxidize the oligosaccharides the gel was treated with $0.2 \%$ periodic acid for $45 \mathrm{~min}$ at $4{ }^{\circ} \mathrm{C}$. The gel was washed with distilled water and stained with Schiff's reagent in dark at $4{ }^{\circ} \mathrm{C}$.

Oxidation of carbohydrate moieties of glycoprotein. In brief, the purified glycoprotein was dissolved in $20 \mathrm{mM}$ phosphate buffer, mixed with an equal amount of $25 \mathrm{mM}$ sodium meta-periodate. The solution was placed in dark at $4{ }^{\circ} \mathrm{C}$ overnight with shaking at regular intervals. After $24 \mathrm{~h}$ the solution was extensively dialyzed against distilled water to remove excess periodate. The protein concentration was determined by Lowry's method before being used for antifungal assays.

Amino acid sequence analysis. The $\mathrm{N}$-terminal amino acid sequence of $U$. indica $29 \mathrm{kDa}$ antifungal glycoprotein was analyzed by means of automated Edman degradation. Microsequencing was carried out using an Applied Biosystem Procise Edman sequencer. N-terminal sequence homology was analyzed using the BLAST database search.

Assay of antifungal activity. All experiments were conducted under sterile condition. Standard antifungal assays were carried out in $100 \times 15 \mathrm{~mm}$ diameter petri dishes, containing $15 \mathrm{ml}$ of potato dextrose agar medium (PDA). For the assay, $0.2 \mathrm{~mm}$ diameter wells were made using sterile cork borer. Fungal spores were harvested from actively growing fungal cultures and suspended in sterile distilled water. After adjusting spore concentration to $5 \times 10^{5}$ spores $/ \mathrm{ml}$, the spore suspension was spread on agar plates evenly and plates were placed at room temperature for $5 \mathrm{~min}$. The test protein sample was passed through $0.4 \mu \mathrm{m}$ filter (Millipore) and added to the well in the spore bearing agar plates. Tris buffer $(25 \mathrm{mM}, \mathrm{pH} 6.8)$ was added on to the control plates. Plates were incubated at $37^{\circ} \mathrm{C}$ for $72 \mathrm{~h}$ in an incubation chamber with near ultraviolet light (NUV) and photographed. Assay was also carried out with different concentrations of protein in order to determine the lowest inhibitory concentration.

Effect of antifungal protein on fungal morphology. To evaluate the effect of purified protein on fungal hyphae, mycelial mats adjacent to the wells were harvested at regular intervals from 0 to $72 \mathrm{~h}$ after application of test solution (10 $\mu \mathrm{g}$ of antifungal protein). The samples were squashed and stained with lactophenol cotton blue, before observing under light microscope (Nikon, China) and photography.
Polyclonal antiserum production. Polyclonal antibodies were raised in New Zealand white male rabbit (weighing $4.0 \mathrm{~kg}$ ) to the purified protein of $29 \mathrm{kDa}$. Approximately $100 \mu \mathrm{g}$ protein was emulsified in complete Freund's adjuvant and administered to rabbit by four subcutaneous and intramuscular injections. Subsequent booster injection was administered with antigen emulsified in incomplete Freund's adjuvant. Blood $(30 \mathrm{ml})$ was collected from the rabbit under slight anesthetization, by making a cut in the marginal ear vein. After collection, blood was allowed to clot for $30-40 \mathrm{~min}$ at $37^{\circ} \mathrm{C}$. Serum was separated from the clot and any remaining insoluble materials were removed by centrifugation at $10,000 \mathrm{rpm}$ for $10 \mathrm{~min}$ at $4{ }^{\circ} \mathrm{C}$.

Purification of antibodies from antiserum. The immunoglobulin from antiserum was purified by ammonium sulfate precipitation, according to Heide and Schwick [30], saturated ammonium sulfate was gradually added to $10 \mathrm{ml}$ of rabbit antiserum with constant stirring at $4^{\circ} \mathrm{C}$. Suspension was kept on ice for $15 \mathrm{~min}$ with occasional stirring followed by centrifugation at $3000 \mathrm{rpm}$ for $30 \mathrm{~min}$ at $4{ }^{\circ} \mathrm{C}$. Ammonium sulfate $(40 \%, 3 \mathrm{ml})$ was added to the precipitate and washed thrice (3000 rpm, $30 \mathrm{~min}$ at $4{ }^{\circ} \mathrm{C}$ ). Precipitate was reconstituted in a small volume of $0.01 \mathrm{M}$ sodium phosphate buffer, $\mathrm{pH} 7.2$, and it was dialyzed against the same buffer for $24 \mathrm{~h}$ with a frequent change of buffer. Precipitate, which appears in this step, was removed by centrifugation and the supernatant was dialyzed against water before the final dialysis against borate-buffered saline $(0.05 \mathrm{M}, \mathrm{pH} 8.4)$.

Immunodiffusion. Immunodiffusion was performed by Ouchterlony double diffusion method. Agarose $(0.65 \%)$ was dissolved in PBS containing sodium azide and poured into petri dishes. Wells were punched in the agarose and peripheral wells were charged with antigen, preimmune serum, BSA, and vehicle (PBS), respectively. The central well contained the antibody $(100 \mu \mathrm{g})$. Precipitin band was allowed to develop at $37^{\circ} \mathrm{C}$ for $24-48 \mathrm{~h}$ in humidified chamber.

Western blot analysis. The purified protein $(10 \mu \mathrm{g})$ was resolved on SDS-PAGE and transblotted to a nitrocellulose membrane using capillary transfer. The membrane was washed with TBS-T $(20 \mathrm{mM}$ Tris- $\mathrm{HCl}, \mathrm{pH} 8.0,150 \mathrm{mM} \mathrm{NaCl}$, and $0.1 \%$ Tween 20 ) and non-specific sites were blocked with TBS-T containing 3\% bovine serum albumin. The blot was treated with primary antibody (antiserum, 1:500 dilution) for $90 \mathrm{~min}$ and washed before being treated with the secondary antibody (anti-rabbit IgG, ALP-linked, 1:2000 dilution) for another $90 \mathrm{~min}$. After washing, the membrane was developed with the coloring reagent 4-nitroblue tertrazolium (NBT)/5-bromo-4-chloro-3indolyl-phosphate 4-toluidine salt (BCIP) at $25^{\circ} \mathrm{C}$ for $4 \mathrm{~min}$. The reaction was terminated by washing the membrane with distilled water for $10 \mathrm{~min}$.

Immunolocalization. Using purified antibody, immunolocalization studies were carried out in order to localize the protein in $U$. indica bulb. Thin transverse paraffin sections of bulb were made using microtone and collected on glass slides. The sections were washed with TBS containing $0.2 \%$ Tween 20 (TBS-T) for $10 \mathrm{~min}$. Non-specific sites were blocked with TBS-T containing 3\% BSA for $1 \mathrm{~h}$. After washing with TBS-T, tissue sections were treated with either pre-immuneserum or primary antibody diluted 100 -fold in TBS-T and washed before being treated with secondary antibody (incubation in dark with FITCconjugated goat anti-rabbit IgG using 1000-fold dilution in TBS-T). The slides were washed extensively using TBS-T. All the processing reactions were done at room temperature. For immunofluorescence detection, sections were examined with Leitz Diaplan Fluorescent microscope, Germany, attached to CCD camera.

\section{Results}

The Indian squill $U$. indica is a plant, which is not consumed either by human or by animals due to its 
toxicity. We were interested in identifying a novel antifungal protein from squill bulb. In the present study we verified for the antifungal activity against some agronomically important plant pathogens. The crude extract of $U$. indica had potent antifungal activity towards $F$. oxysporum. Growth of $R$. solani, A. tenuissima was inhibited to a lesser extent when compared to the inhibition of $F$. oxysporum. Little or no antifungal activity was seen towards other plant pathogens such as $C$. dematium, A. niger, and A. alternata.

\section{Purification of antifungal protein from $U$. indica bulbs}

Urginea indica bulb crude extract was subjected to fractionation with acid extraction followed by column chromatographic techniques in order to identify the component responsible for the antifungal activity. The acid extractable component showed antifungal activity towards $F$. oxysporum and thereby it was subjected to fractionation on a gel filtration column. In Fig. 1A it is shown that the acid extract resolved into two major peaks. Assay of antifungal activity indicated that the activity was associated with peak II. The pooled peak II fraction was further purified using HPLC gel filtration chromatography and of the two peaks that resolved (Fig. 1B) the antifungal activity was associated with the major peak. Upon loading the major peak onto a $\mathrm{C} 18$ RP-HPLC column, the protein eluting at $40 \mathrm{~min}$ with $50 \%$ acetonitrile (Fig. 1C) showed the antifungal activity towards $F$. oxysporum.

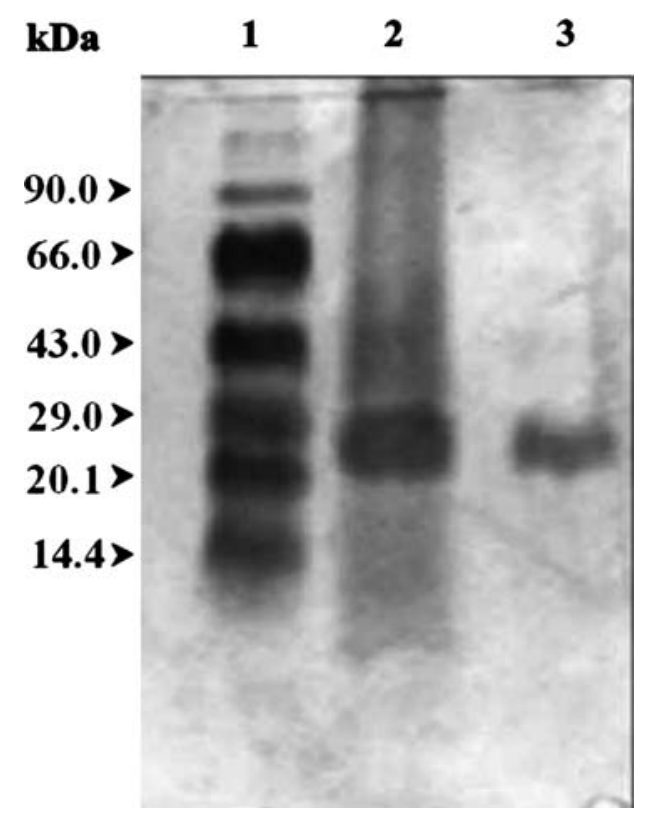

Fig. 2. SDS-PAGE of purified antifungal glycoprotein obtained from HPLC. The migration of molecular mass marker is indicating on the left (lane 1) in kiloDaltons, lane 2 crude extract, lane 3 purified protein.

\section{Characterization of purified protein}

\section{Carbohydrate analysis}

Periodic acid-Schiff staining technique was applied to the detection of glycoprotein. Periodic acid oxidizes the 1,2-glycol groups to aldehyde in polysaccharides, which react with Fuchsin sulfite to form magenta or pink colored bands. The inset in Fig. 1C indicates that the isolated and purified antifungal protein from $U$. indica is a glycoprotein.

The glycoprotein had a molecular mass of $29 \mathrm{kDa}$ as verified by SDS-PAGE (Fig. 2). The purified glycoprotein when estimated for the presence of sugar moiety showed the presence of $300 \mu \mathrm{g}$ of sugar/mg of protein, suggesting that the extent of glycosylation is $30 \%$.

\section{$N$-terminal sequence analysis}

The first $10 \mathrm{~N}$-terminal amino acids of the purified antifungal glycoprotein were determined by automated Edman degradation. By comparing its N-terminal sequence with those available in data banks, we found that it was not identical to any other antifungal proteins published so far. The above sequence; however, exhib-

\begin{tabular}{|c|c|c|c|}
\hline & sidue & & $\%$ identity \\
\hline 1) $29 \mathrm{kDa}$ glycoprotein & 1 & 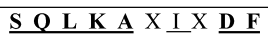 & \\
\hline 3) HMPK & 8 & 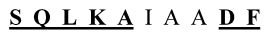 & $70 \%$ \\
\hline 2) Tet $R$ & 34 & 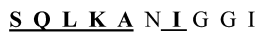 & $60 \%$ \\
\hline 4) Phage-related proteins & 49 & 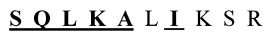 & $60 \%$ \\
\hline 5) PR protein & 40 & 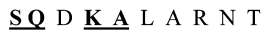 & $40 \%$ \\
\hline
\end{tabular}

Fig. 3. N-terminal amino acid sequence of purified $29 \mathrm{kDa}$ antifungal glycoprotein (1) in comparison with those of hydroxymethyl pyrimidine kinase from Actinobacillus (2), TetR from P. syringe (3), phagerelated proteins from $B$. subtilis (4), and pathogen-related protein from A. thaliana (5). X denotes an unidentified residue. The results shown here are based on 10 amino acids overlap in the $\mathrm{N}$-terminal region.

Table 1

Antifungal activity of the purified protein against various fungal pathogens

\begin{tabular}{ll}
\hline Tested fungal pathogens & Antifungal activity \\
\hline Fusarium oxysporum & ++++ \\
Rhizoctonia solani & ++++ \\
Sclerotium rolfsii & +++ \\
Alternaria tenuissima & ++ \\
Colletotrichum dematium & Not active \\
Aspergillus niger & Not active \\
Alternaria alternata & Not active \\
\hline
\end{tabular}

The distance from the center of the well to the growth of the fungi determined the activity of the protein in this work. Moderately active $(++)$, strongly active $(+++)$, very strongly active $(++++)$ denotes distance. About $10 \mu \mathrm{g}$ of protein/well. Protein $(10 \mu \mathrm{g})$ in $75 \mu \mathrm{l}$ of Tris- $\mathrm{HCl}$ buffer, $\mathrm{pH}$ 6.8, was used for determination of antifungal activity. 
ited $60-70 \%$ sequence identity with the N-terminal sequence of transcriptional regulator from Pseudomonas syringe and hydroxymethyl pyrimidine kinase from $A c$ tinobacillus. The $\mathrm{N}$-terminal sequence of the purified protein also showed $40-50 \%$ sequence identity with pathogen-related protein and phage-related protein, respectively (Fig. 3).

\section{Antifungal activity of purified protein}

The purified protein showed antifungal activity against the agronomically important phytopathogenic fungi such as $F$. oxysporum, $R$. solani, A. tenuissima, and $S$. rolfsii. (Table 1). It maximally inhibited the growth of F. oxysporum (Fig. 4A) at the concentration of $10 \mu \mathrm{g} / \mathrm{well}$. However, the purified protein at a similar concentration had no effect on the growth of $C$. dematium, A. alternata, and $A$. niger. In vitro quantitative assays showed that the growth inhibition caused by $29 \mathrm{kDa}$ protein towards F. oxysporum is dose dependent. An estimated value of approximately $10 \mu \mathrm{g}$ of protein inhibits growth of the above-said fungal pathogen (data not shown).

Examination by light microscopy showed an inhibition of mycelial growth and sporulation. Morphologically, in protein treated fungus, a dramatic shrinkage of

the hyphal tips was observed. Unlike the test sample, the hyphae growing under the influence of sterile Tris- $\mathrm{HCl}$ buffer did not show any obvious growth aberrations (Fig. 4B).

\section{Antifungal activity of oxidized glycoprotein}

To ascertain the functional role of carbohydrate moieties of $29 \mathrm{kDa}$ protein, sugar moieties were oxidized with sodium meta-periodate and $10 \mu \mathrm{g}$ of protein was used for standard antifungal assay. Periodate oxidation of the $29 \mathrm{kDa}$ antifungal glycoprotein showed no antifungal activity (data not shown).

Neutralization of antifungal activity by polyclonal anti$29 \mathrm{kDa}$ antibodies

The $29 \mathrm{kDa}$ antifungal protein from $U$. indica when used for the production of polyclonal antibodies in rabbit showed to be a potent immunogen. In Fig. 5A is shown a single precipitin band upon reactivity of the antigen with rabbit antiserum. As seen in the figure, no cross-reactivity was obtained with PBS (vehicle) or BSA or pre-immune serum.

Western blot analysis indicates strong detection of $29 \mathrm{kDa}$ antifungal protein in crude extract, acid extract,

\section{B Control}

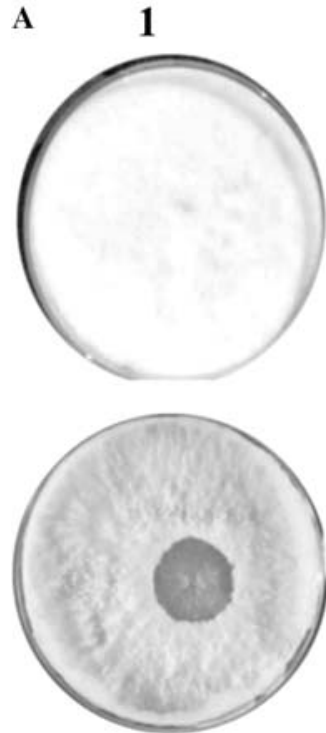

3
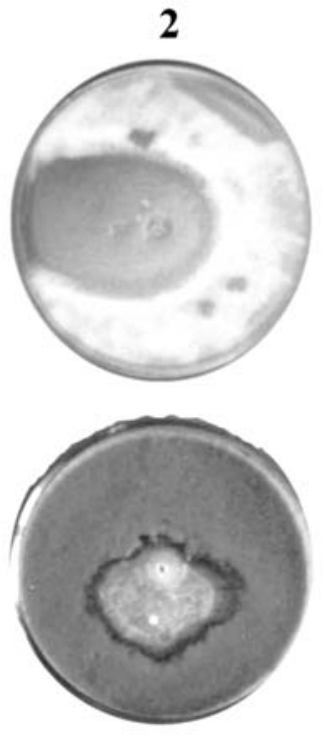

4

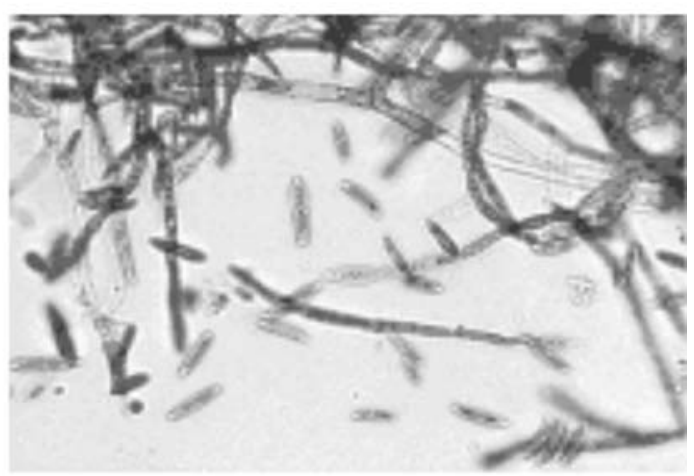

Treated

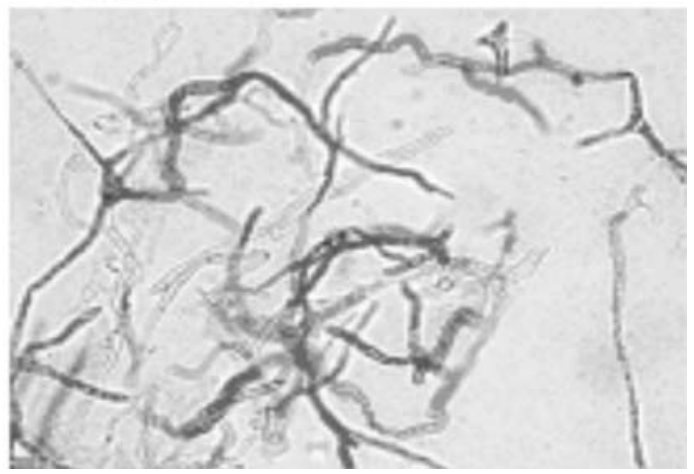

Fig. 4. (A) Antifungal activities in vitro of the purified protein against $F$. oxysporum (2), S. rolfsii (3), and $A$. tenuissima (4). Approximately $10 \mu g$ of purified protein in $50 \mu \mathrm{l}$ of $0.2 \mathrm{mM}$ Tris- $\mathrm{HCl}$ buffer, $\mathrm{pH} 6.8$, was applied onto the wells numbered 2,3 , and 4 . For control, $(F$. oxysporum) $50 \mu \mathrm{l}$ of the above buffer on the well was numbered 1. (B) Differences in morphology of inhibited hyphae. Light microscopic examination of the mycelium of $F$. oxysporum developing around the protein treated wells showed the dramatic shrinkage of hyphae and inhibition of sporulation compared with control hyphae. 


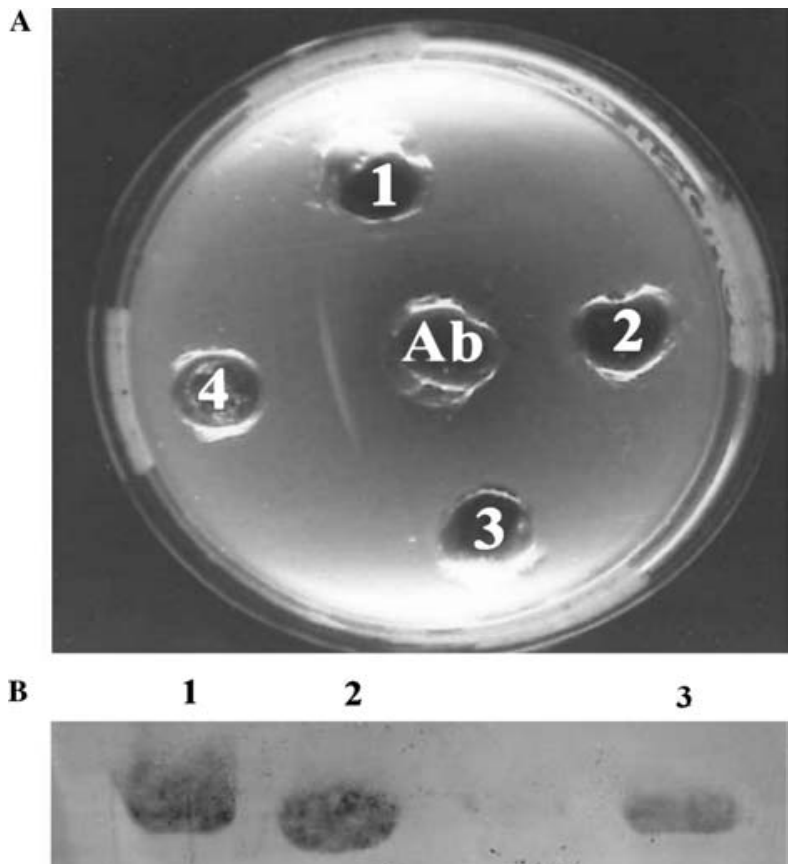

Fig. 5. (A) Immunological data of the $29 \mathrm{kDa}$ antifungal protein: Ouchterlony double diffusion showing a clear precipitin band in well (4) containing the antigen $(20 \mu \mathrm{g})$. Wells 1,2 , and 3 contained PBS, BSA, and pre-immuneserum, respectively. The central well contained the antibody $(20 \mu \mathrm{g})$. (B) Western blot analysis: The $29 \mathrm{kDa}$ antifungal protein is clearly detected in crude homogenate (1), acid extract (2), and purified protein (3).

and purified fractions (Fig. 5B). When the plate with an equal spore load was charged with the purified fraction of protein, clear antifungal activity was visible but with antigen-antibody complex no such antifungal activity was detected, indicating that the antibodies raised are neutralizing ones (data not shown).

\section{Immunolocalization of the $29 \mathrm{kDa}$ protein}

We performed immunofluorescence assay to verify the cellular localization of $U$. indica antifungal protein. The polyclonal antibodies raised against purified antifungal protein recognized the protein in the cell wall (Fig. 6). Typically the peripheral cell layers in the transverse section of the squill bulb stained heavily. The control slides where pre-immune serum was used showed no staining (data not shown).

\section{Discussion}

Urginea indica is a common plant with rich medicinal attributes. $U$. indica is found in sandy soil and also in the hills of lower Himalayas. The extract of $U$. indica bulb contains glycosides and scillirosides and other toxic scilla glycosides and is generally formulated into rodent bites as dried powder [31]. Despite identifying several active compounds from $U$. indica bulb, no studies ex-

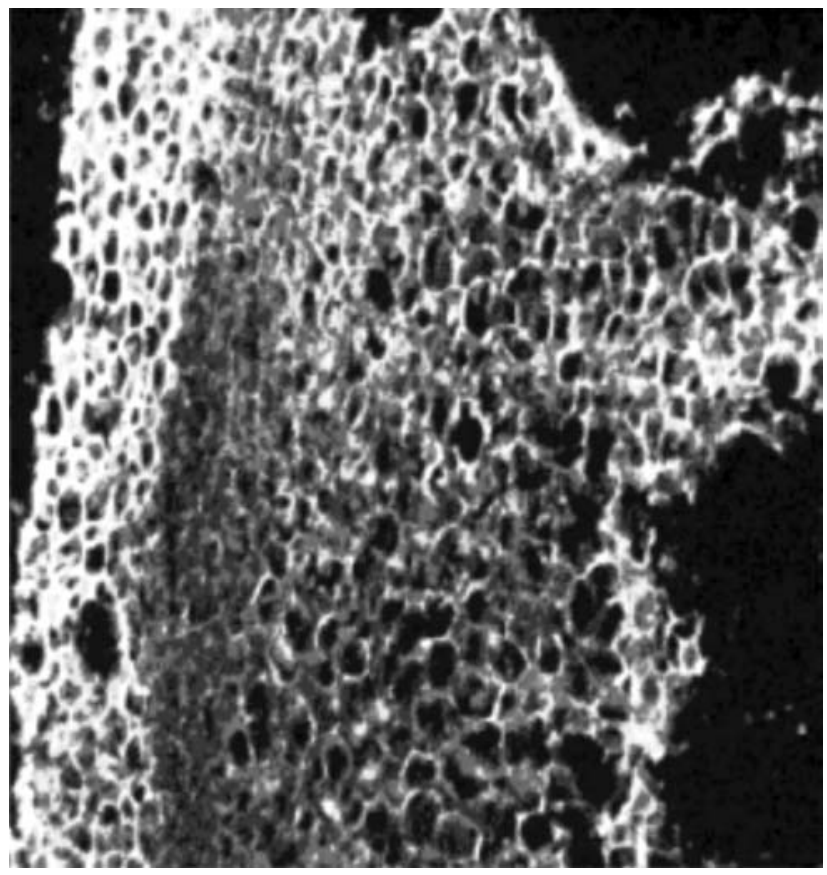

Fig. 6. Localization of antifungal glycoprotein. The $29 \mathrm{kDa}$ antifungal glycoprotein localized in the peripheral cell layers of $U$. indica bulbs, preferentially in the cell wall region.

plain the presence of antifungal proteins. In this report we have identified a novel antifungal glycoprotein from $U$. indica.

Initially when crude extract of $U$. indica bulb was verified for antifungal activity against the agronomically important pathogens, sensitivity towards inhibition of $F$. oxysporum was greater when compared to the antifungal activity towards other fungal species. $F$. oxysporum is a wide-host-range pathogenic fungal species infecting both dicotyledonous and monocotyledonous crops such as mung bean, soybean, azuki bean, cotton, tobacco, potato, maize, and rice.

Further, the acid extractable component of the crude extract showed antifungal activity, suggesting that the protein is of basic nature. The protein was purified to homogeneity and it showed a molecular mass of $29 \mathrm{kDa}$. A majority of antifungal proteins known to date have a molecular weight exceeding $10 \mathrm{kDa}[32,33]$. However, cysteine protease inhibitors from pearl millet seeds and a peptide designated GAPF from Ginkgo biloba leaves are below $10 \mathrm{kDa}$ in molecular weight.

More insight into structure and function of Urginea protein was obtained when the purified protein showed $30 \%$ of carbohydrate content with positive PAS, confirming that the identified antifungal protein is glycoprotein. In recent years, the functional significance of the carbohydrate moieties has been increasingly appreciated. Carbohydrates covalently attached to polypeptide chains can confer many functions to the glycoprotein, for example, resistance to proteolytic degradation, the trans- 
duction of information between cells, and ligand-receptor interactions are a few to mention.

To gain more insight into the structure-function relationship, the purified protein was subjected to sequence analysis and its $\mathrm{N}$-terminal amino acid sequence was determined. Results from the computer search for similarity with other protein sequences showed that the above sequence had no significant similarity with any of the antifungal proteins published so far [34]. Thus, the purified $29 \mathrm{kDa}$ antifungal glycoprotein might be a representative of a novel class of antifungal proteins. These sequences exhibited $70 \% \mathrm{~N}$-terminal sequence identity with hydroxymethyl pyrimidine kinase from Actinobacillus and 55-60\% homology with N-terminal sequence of transcriptional regulator (Tet R) from $P$. syringe and phage-related protein from Bacillus subtilis. It has to be noted that the above proteins (hydroxymethyl pyrimidine kinase, Tet $\mathrm{R}$, and phage-related proteins) have no antifungal activity towards any of the fungi. In addition, although the purified $29 \mathrm{kDa}$ glycoprotein is not a PR protein, it has $40 \%$ sequence identity with the pathogen-related protein from $A$. thaliana.

The fungal growth inhibitory activity of purified protein differed depending on the fungal species. No effect was observed against $C$. dematium, A. alternata, and $A$. niger, partial inhibition was seen for $R$. solani, $A$. tenuissima, and $S$. rolfsii while the growth of $F$. oxysporum was inhibited significantly. When antifungal activity of $U$. indica protein is compared with those of other antifungal proteins, it is observed that Urginea protein displays a much broader specificity than others. Antifungal $28 \mathrm{kDa}$ protein isolated from cowpea [35], $38 \mathrm{kDa}$ Sativin from Pisum sativum [36], exerts a similar effect on $F$. oxysporum but not against $R$. solani. Microscopic observations on morphology of the fungus have shown that growth inhibition by some antifungal proteins is due to swelling and lysis of hyphae $[4,11]$. During the course of this work, fungal growth inhibition was routinely checked microscopically to confirm the microspectrophotometric data. A striking difference in the morphology of inhibited hyphae was apparent between fungi harvested from inhibited zone and those with control hyphae.

Studies on the subcellular localization of antifungal protein revealed that antifungal protein accumulated in the cell wall. Most plant fungal pathogens have an extracellular location during the colonization process. Antifungal proteins potentially active in vivo are proposed to be located in peripheral cell layers. In fact, most antimicrobial proteins have this pattern of expression [22]. It is noteworthy that PR proteins generally exist in many isoforms some of which are stored in the vacuole, while others are deposited in the apoplast. Several studies suggest that antimicrobial activity in vivo especially the enhanced resistance to microbial pathogen is conferred to transgenic plants over expressing thio- nins, defensin [19,13] or LTP [21]. In addition, their constitutive expression and external localization in some plant cells has been described, suggesting a potential contribution to the innate immunity. In fact unlike phytoalexins, which can have adverse effect, the plant antifungal proteins do not seem to be phototropic and can attain high level in seeds and tubers, where they are believed to play a role as protectants. Our results showed that substantial amount of antifungal protein is located at an external position. Thus, it would be accessible to potential pathogens and is a good candidate to be in the first line defense limiting the infection in the early contact with fungi. We currently have no direct proof for the linkage between the growth inhibition effect shown in vitro and activity of protein in plant but according to its potency it could be a good candidate for transgenic overexpression in plants to evaluate and enhance protection against fungal pathogens.

\section{Acknowledgments}

The authors thank for the financial support from Lady Tata Memorial Trust, Mumbai, India (DAV), Center for Scientific and Industrial Research, India (SMN), and Department of Science and Technology, India (TG).

\section{References}

[1] D.J. Bowles, Defense-related proteins in higher plants, Annu. Rev. Biochem. 59 (1990) 873-907.

[2] J. Bol, H. Linthorst, B. Cornelissen, Plant pathogenesis-related proteins induced by virus infection, Annu. Rev. Phytopathol. 28 (1990) 113-138.

[3] C.P. Selitrennikoff, Antifungal proteins, Appl. Environ. Microbiol. 67 (7) (2001) 2883-2894.

[4] F. Mauch, B. Mouch-Mani, T. Boller, Antifungal hydrolases in pea tissue, Plant Physiol. 88 (1988) 936-942.

[5] S. Kauffmann, M. Legrand, P. Geeoffory, B. Friting, Biological function of pathogenesis-related proteins, EMBO J. 6 (1987) 3209-3212.

[6] M. Legrand, S. Kauffmann, P. Geoffory, B. Friting, Biological function of pathogenesis-related proteins: four tobacco PRproteins are chitinases, Proc. Natl. Acad. Sci. USA 84 (1987) 6750-6754.

[7] X.Y. Ye, T.B. Ng, A new antifungal protein and chitinase with prominent macrophage-stimulating activity from seeds of Phaseolus valgaris cv pinto, Biochem. Biophys. Res. Commun. 290 (2002) 813-819.

[8] Xu hu, A.S.N. Reddy, Cloning and expression of a PR5-like protein from Arabidopsis: inhibition of fungal growth by bacterially expressed protein, Plant Mol. Biol. 34 (1997) 949-959.

[9] X.Y. Ye, H.X. Wang, T.B. Ng, First chromatographic isolation of an antifungal thaumatin-like protein from French bean legumes and demonstration of its antifungal activity, Biochem. Biophys. Res.Commun. 263 (1999) 130-134.

[10] K.T. Chu, T.B. Ng, Isolation of a large thaumatin-like antifungal protein from seeds of the kweilin chestnut Castanopsis chinensis, Biochem. Biophys. Res. Commun. 301 (2003) 364-370.

[11] F.R.G. Terras, H.M.E. Schoofs, M.F.C. De Bolle, F.V. Leuven, S.B. Rees, J. Vanderleydent, B.P.A. Cammue, W.F. Broekaert, 
Analysis of two novel classes of plant antifungal proteins from radish (Raphanus sativus) seeds, J. Biol. Chem. 267 (1992) 1530115309 .

[12] F.R.G. Terras, K. Eggermont, V. Kovaleva, N.V. Raikhel, R.W. Osborn, S.B. Rees, S. Torrekens, F. Van Leuven, J. Vanderleyden, J. Commue, W.F. Brockacrt, Small cysteine-rich antifungal proteins from radish: their role in host defense, Plant Cell. 7 (1995) 573-588.

[13] R. Fernandez de Clausen, B. Gonzaezz-Pascual, F. Garcia Olmedo, Susceptibility of phytopathogenic bacteria to wheat purothionins in vitro, P. Carbonero, Appl. Microbiol. 23 (1972) 998-1000.

[14] R. Leah, H. Tommerup, I. Svendsen, J. Mundy, Biochemical and molecular characterization of three barley seed proteins with antifungal properties, J. Biol. Chem. 266 (1991) 1564-1573.

[15] A. Molina, A. Segura, F. Garcia-Olmedo, Lipid transfer proteins (ns LTPs) from barley and maize leaves are potent inhibitors of bacterial and fungal plant pathogens, FEBS Lett. 316 (1993) $119-122$.

[16] C.R. Marina, D.C. Laura, Purification characterization and antifungal properties of a lipid-transfer protein from sunflower (Helianthus annuus) seeds, Physiol. Plantarum 110 (2000) 158-163.

[17] N.V. Raikhel, H.I. Lee, W.F. Broekaert, Structure and function of chitin-binding proteins, Annu. Rev. Plant Physiol. Mol. Biol. 44 (1993) 591-615.

[18] W.F. Broekaert, W. Marien, F.R.G. Terras, M.F.C. De Bolle, P. Proost, J. Van Damme, L. Dillen, M. Claeys, S.B. Rees, J. Vanderleyden, B.P.A. Cammue, Antimicrobial peptides from Amaranthus caudatus seeds with sequence homology to the cysteine/glycene-rich domain of chitin-binding proteins, Biochemistry 31 (1992) 4038-4314.

[19] M.J. Carmona, A. Molina, J.A. Ferandez, J.J. Lopez Fando, F. Garcia Olmendo, Expression of the $\alpha$-thionin gene from barley in tobacco confers enhanced resistance to bacterial pathogens, Plant J. 3 (1993) 457-462.

[20] S. Holtorf, J. Ldwig mullar, K. Apel, H. Bohlmann, High-level expression of a viscotoxin in Arabidopsis thaliana gives enhanced resistance against Plasmodiophora brassicae, Plant Mol. Biol. 36 (1998) 673-680.

[21] A. Molina, F. Garcia Olmendo, Enhanced tolerance to bacterial pathogens caused by the transgenic expression of barley lipid transfer protein LTP-2, Plant J. 12 (1997) 669-675.
[22] W.F. Broekaert, B.P.A. Cammue, M.F.C. De Bolle, K. Thevissen, G.W. De Samblanx, R.W. Osborn, Antimicrobial peptides from plants, Crit. Rev. Plant Sci. 16 (1997) 297-323.

[23] J.A. Hoffmann, F.C. Kafatos, C.A. Janeway, R.A.B. Ezekowitz, Phylogenetic perspectives in innate inmmunity, Science 284 (1999) 1313-1318.

[24] H.K. Hairy shaw, in: J.C. Wills (Ed.), A Dictionary of Flowering Plants and Ferns, Cambridge University Press, Cambridge, 1993.

[25] K. Hemadri, S. Swahari, A new species of Liliaceae from India, Ancient Sci. Life 2 (1982) 78-81.

[26] S. Rangaswamy, S. Subramanian, Chemical investigation of Indian cardiac drugs, J. Sci. Industr. Res. 14B (1955) 78-81.

[27] A.J. Verbiscar, J. Patel, T.F. Banigan, R.A. Schatz, Scilliroside and other scilla compounds in red squill, J. Agric. Food Chem. 34 (1986) 973-979.

[28] U.K. Laemmli, Cleavage of the structural proteins during the assembly of the head of the bacteriophage $T_{4}$, Nature 227 (1970) 680-685.

[29] M. Dubois, K.A. Gillies, J.K. Hamilton, P.A. Rebers, F. Smith, Colorimetric method for determination of sugars and related substances, Anal. Chem. 28 (1956) 350-356.

[30] K. Heide, H.G. Schwick, Preparation of $\gamma$-globulin, in: D.M. Wiev (Ed.), Handbook of Experimental Immunology, vol. 1 , Academic press, New York, 1973.

[31] D. Chitty, Red Squill, Control of Rats and Mice, Oxford University Press, London, 1954, pp. 62-100.

[32] X.Y. Ye, T.B. Ng, Mungin, a novel cyclophilin-like antifungal protein from the Mung bean, Biochem. Biophys. Res. Commun. 273 (2000) 1111-1115.

[33] T.B. Ng, H. Wang, Panaxagin, a new protein from Chinese ginseng possesses antifungal, antiviral, translation-inhibiting and ribonuclease activities, Life Sci. 68 (2001) 739-749.

[34] Q.K. Huynh, J.R. Borgmeyer, C.E. Smith, L.D. Bell, D.M. Shah, Isolation and characterization of a $30 \mathrm{kDa}$ protein with antifungal activity from the leaves of Engelmannia pinnatifida, Biochem. J. 316 (1996) 723-727.

[35] X.Y. Ye, H.X. Wang, T.B. Ng, Structurally dissimilar protein with antiviral and antifungal protein from cow pea (Vigna unguiculata) seeds, Life Sci. 67 (2000) 3199-3207.

[36] X.Y. Ye, H.X. Wang, T.B. Ng, Sativin, a novel antifungal miraculin-like protein isolated from legumes of the sugar snap Pisum sativum var. macrocarpon, Life Sci. 67 (2000) 775-781. 